\title{
Las transformaciones diagramáticas: imágenes y fronteras efímeras
}

\author{
Joaquim Viana *
}

Resumen: Se releva cómo la presión migratoria contemporánea provoca cambios radicales en la gestión de los flujos transfronterizos. La fotografía explora las rutas recorridas por los inmigrantes clandestinos en sus diferentes estados de excepción.

Palabras clave: idas sin vuelta - tecnologías - control.

[Resúmenes en inglés y portugués en la página 150]

${ }^{(*)}$ Joaquim Viana es arquitecto, profesor de la Universidad Federal de Bahia. Profesor del Doctorado en Difusión del Conocimiento (DMMDC/UFBA). Coordinador del TR.OPUS (Grupo de Investigación sobre las Ciudades y Territorios). Investigador Asociado LAB EA4010 AIAC (Arts des images \& art contemporain) y a RETINA.INTERNATIONAL.

El flujo migratorio clandestino entre África (sobretodo el África subsahariana) y Europa expone las tensiones originadas por el paradigma político de las fronteras. Mientras se crean las tecnologías de control de flujos, con sus más refinados sistemas de captación de movimientos y de escucha, los antiguos territorios de soberanía se van transformando por las emergentes inflexiones de resistencia. Las rutas que los migrantes nómadas transitan para llegar a las "puertas" de la Unión Europea se constituyen a partir de puntos singulares, son formados por las relaciones de poder, capaces de eliminar las barreras impuestas por los acuerdos y regímenes fronterizos.

Debido al movimiento global creciente y a las duraderas contradicciones sociales de los dos continentes, la presión migratoria contemporánea provoca cambios radicales en la gestión de los flujos transfronterizos. Mientras las fronteras exteriores de Europa surgen de un pacto de cooperación económica con el fin de avanzar en la protección y el control de los flujos migratorios en el espacio Schengen, los nuevos acontecimientos trágicos tensionan las antiguas "plazas de soberanía" en el territorio africano. El movimiento de la inmigración clandestina, así como los puntos singulares de resistencia que no dejan de aparecer, pueden ser observados, por ejemplo, desde la construcción de vallas en Ceuta y Melilla, dos enclaves españoles que hacen frontera con Marruecos.

Estas ciudades fronterizas experimentan un flujo continuo de actores clandestinos que intentan migrar a Europa desde el Mediterráneo, huyendo de los regímenes de extorsión de gobiernos inestables, hacia las "oportunidades" del mercado global en Europa. Sin em- 
bargo, es importante tener en cuenta que esta acción ilegal casi siempre forma un flujo de retención -o incluso un flujo de ida sin vuelta- y sucede al mismo tiempo en que las políticas entre las nuevas "zonas de vecindad" establecen grados moderados para el control y selección en las fronteras. Esta moderación se ajusta a la medida en que son creados y compartidos algunos dispositivos de control entre África y Europa.

En junio de 2014, Marruecos se convirtió en el primer país en firmar un decreto para el acogimiento de los inmigrantes ilegales capturados en suelo europeo que supuestamente han cruzado las fronteras de Europa desde su territorio. A cambio de esta "acogida", la Unión Europea propuso una medida de ayuda a la policía de control de fronteras y un tratado de movilidad facilitará el ingreso de estudiantes y empresarios marroquíes en el territorio Schengen. Por otro lado, la retención y la expulsión de los inmigrantes clandestinos, verdaderos hombres sin rostros, que cruzan ilegalmente las fronteras establecidas por Europa, develan las políticas que resultan de los procesos históricos que siempre han creado mecanismos para fomentar choques de civilizaciones y evaluar sus políticas de control de fronteras. Si, inicialmente, los estados estaban preocupados por trazar una anatomía política de los cuerpos, con el fin de constituir puntos de referencia que demarcaran rígidamente los flujos de escape de las fronteras, hoy se debe pensar en un régimen de naturaleza distinta capaz de diseñar una biopolítica de la población. De esta forma, la alternancia de los diferentes regímenes establece nuevas formas y nuevas funciones para las fronteras, haciéndolas más fluidas y creando fronteras efímeras que, paradójicamente, demarcan un violento régimen de control.

Los trágicos acontecimientos observados entre agosto y octubre de 2005, cuando varios inmigrantes subsaharianos acampados en las cercanías de los enclaves españoles de Melilla y Ceuta intentaron cruzar las fronteras de alta seguridad hacia el territorio europeo y fueron retenidos por los CETI (Centros de Estancia Temporal de Inmigrantes), no dejan de multiplicarse y todavía resuenan como una preocupación inminente para las políticas de control de fronteras. Las imágenes que fueron capturadas/formadas por las cámaras de vigilancia instaladas en los muros mediterráneos de Ceuta y Melilla nos develan un ingenioso sintagma de lo visible que funciona como axioma del Estado, en la medida en que cuantifica y estratifica los cuerpos de los migrantes ilegales. Las imágenes son fabricadas como unidades significativas en función de un núcleo enunciativo/formativo de Estado. Mucho más que el registro de una acción clandestina de cuerpos que cruzan las fronteras que separan el África del sueño "El dorado" europeo, las imágenes nos permiten ver el espesor de los Estados. Por lo tanto, la mediatización generalizada de las imágenes que "develan" el flujo migratorio clandestino entre las fronteras europeas, expone no sólo el poder de las nuevas tecnologías de vigilancia y captura, sino también la formación de bloques de imágenes como elemento teoremático del Estado. Estas imágenes agrupadas y mediatizadas sirven para determinar el flujo de retención de los hombres sin rostro que rebasan ilegalmente las barreras y, a la vez, dan a conocer el grado de apertura y la permeabilidad del control selectivo de las fronteras que son resultantes de los acuerdos entre los estados. AntoineD'Agata, en su exposición nombrada Odysseia, que tuvo lugar en el Musée des Civilisations de l'Europe et de la Méditerranée en Marsella, en septiembre de 2013, supo evidenciar muy bien este mecanismo de imágenes como una paradoja de nuestra contemporaneidad. Mientras el mass-media crea un bloque de imágenes sin potencia como una 
sucesión de imágenes clichés (en la repetición incesante de los informes periódicos y las nuevas tecnologías en la red) para tratar sobre los hechos ocurridos en las fronteras de Europa, D’Agata explora, a partir de la potencia de otras imágenes, de relatos singulares y de vestigios hechos video de las rutas recorridas por los inmigrantes clandestinos, diferentes estados de excepción. Dada la evidencia de que, como nos dice Serge Daney, "nuestra sociedad produce más imágenes y sonidos de lo que puede digerir" la densidad de las imágenes - imágenes periféricas - producidas por D’Agata, se nos presenta como reparación, que muestra la excepción irremediable de los flujos de cuerpos ilegales que cruzan las fronteras de Europa, que se lanzan por un viaje sin vuelta (ida sin vuelta/aller sans retour). En la medida de esa reparación, la Odysseia de AntoineD’Agata está cargada de perseverancia, pues detalla con mucho cuidado y con lucidez lo efímero de las fronteras que se debe a las mutaciones diagramáticas, en función de las relaciones y activaciones de fuerzas minoritarias renovadas, en la medida en que los cuerpos nómadas cruzan el Mediterráneo y otros límites fronterizos del bloque europeo. Por tanto, es posible percibir que la acción documentalista de D'Agata avanza ante la fragilidad de las vidas expuestas, poniendo de relieve sus debilidades, develando sus desplazamientos, sus miedos, sus angustias, que a la vez son potencias que efectivizan la destitución de las fronteras. No se puede escapar ileso de la Odysseia de los hombres sin rostro que irrumpen las barreras de la Unión Europea, que se enfrentan a terribles peligros en busca de la supervivencia, viviendo cada día a la espera de un porvenir acogedor y que forman, casi siempre, la mano de obra invisible de Europa. Por otra lado, estos nuevos Ulises exponenciales, que derivan de Évros, Bicske, Choucha, Rohovce, Nador, Magreb y muchos otros territorios en crisis, alimentan los discursos forjados por el "control democrático", que no se cansa de construir nuevas fronteras, cada vez más efímeras, pero múltiples, al tiempo que propagan las imágenes constantes de la inseguridad y del terrorismo en suelo europeo.

Las experiencias de los cruces sin vuelta de estos nuevos nómadas fronterizos se constituyen como el revés de la tela de los proyectos políticos y culturales diseñados para Europa. Estos proyectos crean las ciudades límite, o sea, las ciudades fronteras, eligiendo a cada primavera las ciudades europeas de la cultura en función de lucrativas remodelaciones urbanas. Ellos fuerzan las transformaciones de nuevos axiomas que son promulgados por la fuerza del Estado y fomentados por la violencia de un sentido común explorado por los mass-media. Ellos alimentan los procesos de subjetivación, con la finalidad de proponer la homogeneización de los contenidos, la homogeneización de los cuerpos europeos, haciéndolos dependientes de una escala jerárquica e identitaria formada por un ordenamiento constituyente. Este poder constituyente de la cultura puede dar lugar a una exposición de una semiología general que subyuga lo dimensional, la métrica, para crear planes de organización entre fronteras, leyes y prácticas de segregación que forjan una imagen de ciudad identitaria como la conformación de un código legal unificado. He aquí la formación de la más ingeniosa frontera efímera constituida en el suelo europeo. El imperativo de este sistema se hace dogmatismo del propio Estado y acaba por dar lugar a las conformaciones de un violento proceso de homogeneización de las metrópolis europeas contemporáneas, lo que se debe en gran medida a la función derivativa de una nueva sintaxis económica global que determina las delimitaciones de las fronteras efímeras, teniendo en cuenta los mejores índices de consumo. 
Abstract: The article analyzes the contemporary migratory pressure that causes radical changes in transboundary flow management. Photography explores the paths covered by illegal inmigrants in their different exception states.

Key words: no way back - technologies - control.

Resumo: O escrito trata sobre a pressão migratória contemporânea que produz câmbios radicais na gestão dos fluxos nas fronteiras. A fotografia explora os caminhos percorridos pelos imigrantes clandestinos em seus diferentes estados de exceção.

Palavras chave: idas sem volta - tecnologias - controle. 